\title{
Sulpiride の乳腺刺激作用に関する研究
}

第 2 編 Sulpiride の乳腺刺激作用機序解析の試み

\author{
関西医科大学病理学教室（指導 森井外吉教授）
}

専攻生藤 井登志之

一内容目次一

\section{I 緒論}

III実験材料および実験方法

1）内分泌腺剔出ラ，トにおける Sulp1ride 投与 実験

2) Sulp $1 r_{1}$ de 投与ウサギにおける体温測定

3) Sulp $1 r_{1}$ de 投与ラ,トの血清, 下垂体組織の プロラクチン測定

\section{I 緒 論}

前編1) において, 胃, 十二指腸潰瘍に冶療的効果を示 すものとして開発された Sulp 1 ride が, ラ,ト乳腺に 肥大増生効果を示すことを述べた。このような薬物の乳 腺刺激作用については，最近次のような考学が発表され ている.すなわち, 先ず, Sulmanら2)および Polishuk ら3) は, Chlorpromazine は下垂体に作用することに よりプロラクチンを介して乳腺の肥大増殖をうながすも のてあると考えた.ついてその後, Ben-Davidら4は, Perphenazıne が間脸下垂体系に作用して median eminence の領域ての Prolactin-1nhibiting-factor の産生分泌を抑制し, その結果下垂体からのプロラクチ ンの産生を亢進するものと考えている.

今回, 著者は, Sulpir1deがどのようなメカニズムに より乳腺刺激効果を示すかにつき, 次の四種の実験を試 みた. 先ず, (1)下垂体, 卵巣または副腎をそれそれ剔出 した内分泌異常ラ トトおける Sulp 1 ride の効果を形 態学的に検討した. (2)一般の向精神薬との異同を知る目 的て, その薬理効果の一つてある体温降下作用が Sulpiride投与ウサギにみられるか否かを測定した。乳腺組 織の分化発達そして乳汁分泌にはステロイドホルモン， インシュリンと共に, プロラクチンが重要な役割を潰し ていることは今更いうまてもない.このプロラクチンは 下垂体前葉好酸性細胞て産生分泌され，その機能は間脳 の神経内分泌でコントロールされている. Sulp1rideが 果してプロラクチン分泌を促しているか, 若しそうなら
4 ）放射性 Sulpiride のラノトにおける体内分布 観察

III 実験結果

IV 考察

$\mathrm{V}$ 結論

VI 交献

VII 写真説明

ば下垂体, 間脳のいずれに作用しているかなどが注目さ れる.それて (3) Sulpiride 投与ラ,トにみられる血清 および下垂体組織内のプロラクチンの経時的変化や(4)放 射性 Sulpiride 投与ラ,トにおけるその体内分布の追 跡などを主に観察し, Sulpirideの直接作用器官を推論 した.

\section{II 実験材料および実験方法}

実験 I ; 内分泌腺剔出ラットにおける Sulpiride 投 与実験

1）下垂体剔出動物を用いた実験

体重150g 前後の Sprague-Dawley 系雌ラントを Pentobarbital で軽く麻酔し, 外耳道法5)により下垂 剔出を行なった。 その後実験期間中を通じ，10\%庶糖液 を飲料水とし, 動物は高蛋白食で飼育した.

高蛋白食組成

$$
\begin{aligned}
& \text { ミルクカゼイン } 35 \% \\
& \text { コーンスターチ } 28 \% \\
& \alpha \text {-澱粉 } 10 \% \\
& \text { 粉末沪紙 } 8 \% \\
& \text { リノールサラダ油 } 6 \% \\
& \text { 無機塩類混合 } \quad 5 \% \\
& \text { グラニユ糖 } \quad 6 \% \text { \% } \\
& \text { ビタミン混合 } \quad 2 \%
\end{aligned}
$$

手術後 3 日目に, 動物を以下の 5 群に别け，それから 2 週間各処置を加えた。

A) Sulpiride $100 \mathrm{mg} / \mathrm{kg}$ 連日皮下投与群， 5 匹. 
B） Sulp $1 r_{1}$ de $200 \mathrm{mg} / \mathrm{kg}$ 連日皮下投与群， 3 匹.

C ) Estradiol-17 $\beta$ 10 $/$ 動物連日皮下投与群. 5 匹,

D) Estradiol-17 $\beta$ 10r/動物およひSulp $1 r_{1}$ de 100 $\mathrm{mg} / \mathrm{kg}$ 連日併用皮下投与群, 3 匹.

E）生理食塩水連日皮下投与群，4匹.

11）卵栄剔出動物を用いた実験

体重200g 前後の Sprague-Dawley 系雌ラントを Ether て麻酔し, 背側部より左右卵巣をすみやかに剔出, 以下の実験群に別け, 術後 2 週間各処置を行なった.

A) Sulp $1 r_{1} d e 100 \mathrm{mg} / \mathrm{kg}$ 連日皮下投与群， 3 匹

B) Estradiol 10r/動物連日皮下投与群, 3 匹.

C ）Estrad 101 10r/動物および Sulp 1 r 1 de 100mg/ $\mathrm{kg}$ 連日仾用皮下投与群， 3 匹.

D）生理食塩水連日皮下投与群， 3 匹.

111）副腎剔出動物を用いた実験

体重200g 前後の Sprague-Dawley 系雌ラントを Etherて麻醉し, 背側部より左右副腎をリングピンセ， トを用い迅速に剔出した. 手術後動物の生存日数延長を はかるため，1％食塩水它飲料水として与えた．副腎剔 出後 3 日目より, 5 匹の動物に Sulp 1 r 1 de $100 \mathrm{mg} / \mathrm{kg}$ を, 5 匹の動物に生理食塩水を, 各々 2 週間連日皮下技与し た.

以上の 3 種の実験に応用された上記有効動物は，すへ て最終注射後24時間て断頭にて屠殺し, 乳腺, 主要内分 泌腺, 子宮およひ胸腺の重量をトーシオンハランスなら びに上血天秤て測定した。なお，各実駼群より採取した 贜器は $10 \%$ ホルマリンて固定後, 組織標本を作製, 病理 組織学的検索を行なった

\section{実験II；Sulpiride 投与ウサギにおける体温変動測定} 体重 $2 \mathrm{~kg}$ 前後の成孰雄ウサギを 3 匹すつ 3 群に別け, 第 1 群には $100 \mathrm{mg} / \mathrm{kg} の S u l p_{1} \mathrm{r}_{1}$ de を, 第 2 群には $5 \mathrm{mg} /$ $\mathrm{kg}$ の Chlorpromazine を, 第 3 群には生理食塩水を各 々皮下投与した.各動物はその後, 1 時間ごとに 6 時間, 直腸温を微小体温自動測定器 (新川電器) 飞唀導, 測定 を行なった。

実験 III；Sulpiride 投与ラットの血清 下垂体組織の プロラクチン測定

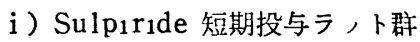

体重200g前後の雌ラ，トを約 2 週間性周期を観察し， 周期が正常である動物を実験に供した. Sulp1r1de 100 $\mathrm{mg} / \mathrm{kg}$ の初回投与以静止期に行ない，24時間まてに屠殺 した 1 回投与群扩よひ $3,5,7$ 日間の連続投与群とを 設定した. 測定材料は, Sulp $1 r_{1}$ de 1 回投与後それそれ $6,12,24$ 時間後, および $3,5,7$ 日間連続投与後それそ
れ24時間後に採取された血清および一部下垂体てある. なお，対照群に注同程度の体重の静止期動物を用いた。

11) Sulpiride 長期投与ラ, ト群

生後 6 週令の雌ラ トト Sulp 1 r r de $100 \mathrm{mg} / \mathrm{kg}$ または 生理食塩水をそれそれ 1 か月間連日皮下投与した。投与 終了24時間後に動物を屠殺し, 血清および下垂体を採取 した.

これらプロラクチン測定実験における試籵の採取はな るべく午前中に限るよう努めた，得られた血清および下 垂体組織は採取後直ちに一20Cのデープフリーサーに入 れ，測定するまて保存した．プロラクチン濃度の測定は 国立がんセンター・長沢弘博士に依頼した。これは NIAMDD-Rat-RP妾使用した rad101mmunoassay法 6)て行なわれたものてある.

\section{実験IV ; 放射性 Sulpiride のラットにおける体内分}

\section{布観察}

動物は体重200g前後の Sprague-Dawley 系雌ラート を 1 群 2 匹ずつ計 8 匹使用した。用いた薬郕は図に示す ごとき ${ }^{14} \mathrm{C}-S_{1} \mathrm{Su}_{1} \mathrm{r}_{1} \mathrm{de}$ で, 藤沢薬品研究所て合成され たものである. その $2 \mathrm{mg} / \mathrm{kg}$ (放射能量は $1.7 \sim 2.2 \mu \mathrm{C}_{1}$ ) を筋肉内投与を行なった. 処置後 30 分, 60 分, 3 時間, 24 時間て各々 2 匹のラ, トを断頭屠殺し, 直ちに被験臓 器の湿重量を測定した。な㧍, 脳は大脳頭頂葉, 視床下 部の 2 部（視床下部として前域は視束交叉, 側域は左右 の視床下部裂溝, 後域は乳頭体で境される部分を深さ約 2 m範囲て採取した. 頭頂葉として, 前頭葉前極より $8 \mathrm{~mm}$ 後方の前額面を前域, それより $7 \mathrm{~mm}$ 後方を後域と し, 大細縦裂の左右それそれ約 $7 \mathrm{~mm}$ 側方を側域とした灰 白質の部分を採取した。）に分割測定した.

被験臓器はその後約18時間凍結乾燥をおこない，これ を乳鉢て粉末にし, その $10 \mathrm{mg}$ (小藏器は全重量)を秤量, ソルエン $1.0 \mathrm{ml}$ を加え, $37^{\circ} \mathrm{C}$ C 1 昼夜放置溶解させた.

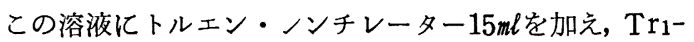
Carb 3375型液体ノンチレーションカウンター(Packard Instrument）て測定した.<smiles>CCN1CCCC1CNC(=O)[C@@H]1C(OC)=CC=C1S(N)(=O)=O</smiles>

III 実験 結果

実験 I ; 内分泌腺剔出ラットにおける Sulpiride 投 与実験 
i）下垂体剔出動物に Sulp 1 ride の $100 \mathrm{mg} / \mathrm{kg}$ および $200 \mathrm{mg} / \mathrm{kg}$ を皮下投与し，その乳腺および内分泌腺の平均 重量への影響を第 1 表に要約した. Sulp 1 ride による乳 腺重量増加は, 下垂体剔出動物において全く認められ ず, 組織学的所見(写真 3 ) 亿おいても無処置対照群(写 真1）に比べてやや萎縮傾向にあり，下垂体剔出群対照 （写真 2）と大差を認めなかった。下垂体剔出動物に
Estrad101-17 $\beta$ の10r/動物単独または Sulp1r1de と併 用投与したが, 乳腺重量, 組織学的所見 (写真 4$)$ とも 明らかな变化はみられなかった なお, Sulpiride投与 群て, ホルモン関連器官重量への効果はみられなかった が，Estrad 101 投与群ては当然のことながら，子宮重量 の増加と胸腺の退縮をみた。

11）卵巣剔出動物における諸実験群の乳腺, 内分泌腺

第 1 表 下垂体剔出雌ラ，トの乳腺および主要内分泌㶓器の平均重量（mg）

\begin{tabular}{|c|c|c|c|c|c|c|c|c|}
\hline 群 & $\begin{array}{l}\text { 例 } \\
\text { 数 }\end{array}$ & $\begin{array}{l}\text { 終体重 } \\
(\mathrm{g})\end{array}$ & 乳腺 & 副腎 & 卵巣 & 子宮 & 甲状腺 & 胸腺 \\
\hline $\begin{array}{l}\text { Sulp } 1 \text { ride } \\
100 \mathrm{mg} / \mathrm{kg}\end{array}$ & 5 & 148 & 634 & 13.6 & 30.2 & 105 & 8 & 276 \\
\hline $\begin{array}{l}\text { Sulpiride } \\
200 \mathrm{mg} / \mathrm{kg}\end{array}$ & 3 & 141 & 487 & 14.7 & 34.3 & 91 & 9 & 254 \\
\hline $\begin{array}{c}\text { Estradiol } \\
\text { 10r/an1mal }\end{array}$ & 5 & 141 & 384 & 14.8 & 36.0 & 442 & 8 & 168 \\
\hline $\begin{array}{c}\text { Sulp1 } \mathrm{r}_{1 \mathrm{de}} 100 \mathrm{mg} / \mathrm{kg} \\
+ \\
\text { Estrad } 10 \mathrm{ol} 10 \mathrm{r} / \mathrm{an}_{1} \mathrm{mal}\end{array}$ & 3 & 137 & 570 & 17.7 & 35.7 & 497 & 8 & 198 \\
\hline Control & 4 & 146 & 576 & 130 & 35.8 & 95 & 8 & 326 \\
\hline
\end{tabular}

の平均重量におよぼす Sulpiride の効果を第 2 表に示 した. 卵巣剔出動物への Sulp pride 投与は, 乳腺重量 および組織学的所見（写真5）にほんのわずかな増殖作 用をうかがわせる。 しかし，卵剔ラ，トに対する Est$\operatorname{rad}_{101}$ 単独投与(写真 6 ) や Sulp $1 \mathrm{r}_{1} \mathrm{de}_{\mathrm{d}} \cdot \mathrm{Estrad}_{101}$ 併
用投与群（写真 7）にみられる乳腺腺葉の発育, 腺房の 肥大拡張に比し，非常に弱いものてある。

この実験において, Estrad10lの子宮および胸腺への 影響は認められるが, 乳腺以外のホルモン関連器官への Sulp1r1deの影響はみいだされなかった。

第 2 表 卵巣剔出雌ラ，トの乳腺および主要内分泌臟器の平均重量（mg）

\begin{tabular}{c|c|c|cccccc}
\hline 実 験 群 & $\begin{array}{c}\text { 例 } \\
\text { 数 }\end{array}$ & $\begin{array}{c}\text { 終体重 } \\
(\mathrm{g})\end{array}$ & 乳腺 & 副腎 & 下垂体 & 子宮 & 甲状腺 & 胸腺 \\
\hline $\begin{array}{c}\text { Sulpiride } \\
\text { 100mg/kg }\end{array}$ & 3 & 216 & 570 & 64 & 14 & 130 & 17 & 863 \\
\hline $\begin{array}{c}\text { Estrad 1ol } \\
10 r / a n 1 m a l\end{array}$ & 3 & 190 & 653 & 62 & 14 & 362 & 14 & 550 \\
\hline $\begin{array}{c}\text { Sulp1ride 100mg/kg } \\
+ \\
\text { Estradiol 10r/an1mal }\end{array}$ & 3 & 202 & 907 & 59 & 17 & 402 & 18 & 417 \\
\hline Control & 3 & 198 & 543 & 54 & 11 & 160 & 14 & 840 \\
\hline
\end{tabular}

ii1）副腎剔出動物を用いた観察における Sulp 1 r rde 投与の影響を第 3 表に示した。副腎剔出動物における Sulp $1 r_{1}$ de の乳腺刺激作用は, 乳腺組織の重量および組 織学的所見（写真 8) て明らか認められた。 また， Sulp 1ride 投与によりもたらされる卵巣および子宮重量
の軽度低下も先にわれわれが正常ラ，トを用いて行なっ たと同様の結果であった 7 .

実験 III；Sulpiride 投与ウサギにおける体温変動則定 対昭群, Sulp 1 r $_{1}$ de投与群拉よびChlorpromazine投 与群のそれぞれにつき，その経時的体温変動を第 4 表に 
示した 対昭群および Sulp 1 r rde 投与群の体温変動は 測定中ほとえど認められなかった。一方, Chlorpromazine 投与群は投与 1 時間後より体温の著明な低下が
みられ， 2 時間後に最も低值となり, 以後徐々に回復傾 向を示すが，しかし 6 時間の測定時間内には完全な回復 はみられなかった。

第 3 表 副腎剔出雌ラ，トの乳腺㧍よひ主要内分泌臟器の平均重量（mg）

\begin{tabular}{c|c|c|cccccc}
\hline 実 験 群 & $\begin{array}{c}\text { 例 } \\
\text { 数 }\end{array}$ & $\begin{array}{c}\text { 終体重 } \\
(\mathrm{g})\end{array}$ & 乳腺 & 卵巣 & 下垂体 & 子宮 & 甲状腺 & 胸腺 \\
\hline $\begin{array}{c}\text { Sulp } 1 \mathrm{r} 1 \mathrm{de} \\
100 \mathrm{mg} / \mathrm{kg}\end{array}$ & 5 & 223 & 685 & 71.0 & 13.1 & 317 & 15 & 737 \\
\hline Control & 5 & 212 & 314 & 74.9 & 12.4 & 388 & 13 & 612 \\
\hline
\end{tabular}

第 4 表 正常ウサギ体温に及ぼす Sulp $1 r_{1}$ de および Chlorpromazine の影響

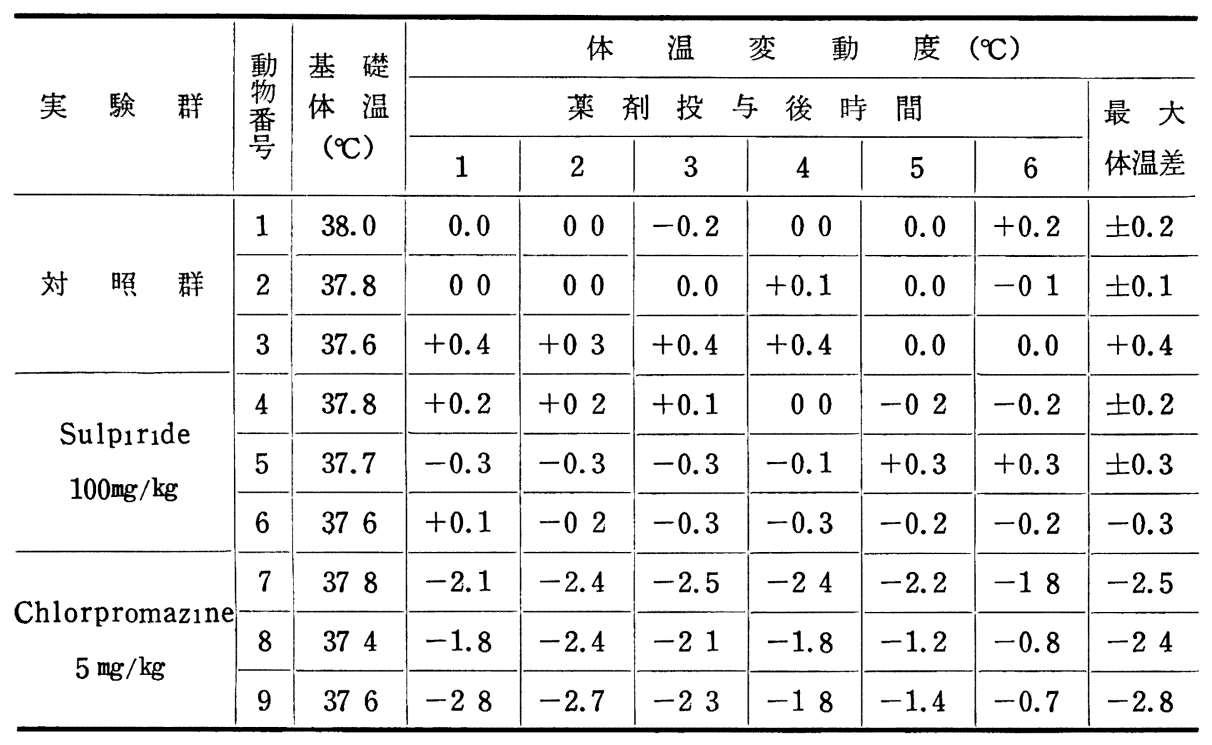

第 5 表 プロラクチンの血清濃度および下垂体組織内含量に及ぼす Sulpir 1 de 短期投与の影響

\begin{tabular}{|c|c|c|c|c|c|c|c|c|c|}
\hline \multirow{2}{*}{ 害 験 群 } & \multirow{2}{*}{$\begin{array}{c}\text { 投与後 } \\
\text { 採血時期 }\end{array}$} & \multicolumn{4}{|c|}{$\begin{array}{c}\begin{array}{c}\text { 血倩ブロラクチン濃度 } \\
\text { (ng/ml) }\end{array} \\
\end{array}$} & \multicolumn{4}{|c|}{$\begin{array}{c}\text { 下垂体組織内プロラクチン含量 } \\
(\mu \mathrm{g} / \mathrm{A} . \mathrm{P} .)\end{array}$} \\
\hline & & 実 & 測 & 值 & 平 均 & 実 & 測 & 值 & 平 均 \\
\hline 無処置群 & - & 107 & 132 & 96 & 112 & 9.5 & 110 & 7.8 & 9.4 \\
\hline \multirow{6}{*}{$\begin{array}{l}\text { Sulpiride } \\
\text { 投 与 群 }\end{array}$} & 6 時間 & 280 & 290 & 276 & 282 & & - & & - \\
\hline & 12時間 & 357 & 327 & 326 & 337 & 78 & 9.7 & 9.0 & 88 \\
\hline & 24時間 & 272 & 239 & 224 & 245 & 15.4 & 13.0 & 14.3 & 14.2 \\
\hline & 日 & 181 & 105 & 157 & 148 & & - & & - \\
\hline & 日 & 123 & 94 & 94 & 104 & & - & & - \\
\hline & 日 & 107 & 101 & 80 & 96 & & - & & - \\
\hline
\end{tabular}


実験III；Sulpiride 投与ラットの血清，下垂体組織の プロラクチン測定

1) Sulp 1 ride 短期投与ラ, ト群

Sulp $1 r_{1}$ de 単一投与または区復投与したラ，トの血清 フロラクチン濃度およひ下垂体組織内プロラクチン含量 を第 5 表に示した。 無処置, 静止期ラ，トの血清中ブロ ラクチン量 $112 \mathrm{ng} / \mathrm{ml}$ に比へ, Sulp 1 r 1de 投与 6 時間後 ではすてに2.5倍に增加, 12時間後ては 3 倍の $337 \mathrm{ng} / \mathrm{ml}$ に上昇, 測定期間中最も高い值を示した. その後, 徐々 に減少する傾向がうかがわれ，24時間後には無処置動物 の約 2 倍の值にまて低下した．反復投与を行なった結果 ては 5 日間連続投与後および 1 週間連続投与後の血清中 濃度はともに無処置群のプロラクチン濃度と同様の值を
示した。

下垂体組織内ブロラクチン含量を Sulp1ride 投与 12 時間後および24時間後て測定した. 投与12時間後の值注 $8.8 \mu \mathrm{g} / \mathrm{A}$. P. $\tau ，$ 無処置動物 $9.4 \mu \mathrm{g} / \mathrm{A}$.P. と大差を認め

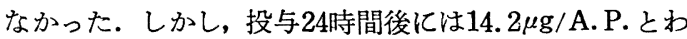
ずかに上昇する傾向を示した。

11） Sulpiride 長期投与ラ,ト群

Sulpirideを 1 か月間連続投与したラトの血猜ブロ ラクチン濃度㧍よび下垂体組織内プロラクチン含量を第 6 表に示した.

少数例の測定てはあるが，血清中および下垂体組織内 プロラクチン濃度いずれも，無処群と Sulp $1 \mathrm{r}_{1}$ de 投与 群て明らかな差違を認めなかった。

第 6 表 プロラクチンの血清濃度および下垂体組織内含量に及ぼす Sulpiride 長期投与の影響

\begin{tabular}{|c|c|c|c|c|c|c|}
\hline \multirow{2}{*}{ 実 験 群 } & \multirow{2}{*}{$\begin{array}{l}\text { 動 物 } \\
\text { 番 号 }\end{array}$} & \multicolumn{3}{|c|}{$\begin{array}{c}\text { 血清プロラクチン濃度 } \\
\text { (ng/ml) }\end{array}$} & \multicolumn{2}{|c|}{$\begin{array}{c}\text { 下垂体組織内プロラクチン含 } \\
(\mu \mathrm{g} / \mathrm{A} . \mathrm{P} .)\end{array}$} \\
\hline & & 実 測 值 & 平 & 均 & 実 測 值 & 平 \\
\hline \multirow{3}{*}{ 無処 置 群 } & 1 & 91 & \multirow{3}{*}{\multicolumn{2}{|c|}{76}} & 11.0 & \multirow{3}{*}{8.9} \\
\hline & 2 & 81 & & & 7.1 & \\
\hline & 3 & 57 & & & 8.6 & \\
\hline Sulpiride & 4 & 115 & \multirow{3}{*}{\multicolumn{2}{|c|}{91}} & 123 & \multirow{3}{*}{10.8} \\
\hline \multirow{2}{*}{ 投 与 群 } & 5 & 71 & & & 9.2 & \\
\hline & 6 & 86 & & & 11.0 & \\
\hline
\end{tabular}

\section{実験 IV ，放射性 Sulpiride のラットにおける体内分 布観察}

${ }^{14} \mathrm{C}-\mathrm{Sulp} 1$ rideを筋肉内投与し，その後，経時的に体 内分布状態を観察した結果を第 7 表に要約した。

下垂体内 Sulp 1 ride含有量が投与後 30 分, 60 分て著明 飞高く，以前に行なったSulp $1 r_{1}$ deの体内分布実験8)て
みられた下垂体内分布量の高值とよく一致した結果を得 た. 脳の皮質部分として頭頂葉を，さらに視床下部をも 取り出し，同様に莧物の分布状態を観察したが，いずれ も多くの分布量は認められなかった。

乳腺脂肪織内の Sulp 1 ride含有量は投与 30 分後よりあ まり多くなく，時間の経過とともにしだいに減少した

第 7 表 ${ }^{14} \mathrm{C}-\mathrm{Sulp}_{1} \mathrm{r}_{1} \mathrm{de}$ の経時的臓器内分布変動（藏器 $1 \mathrm{~g}$ 当りの薬物量 $(\gamma)$ )

\begin{tabular}{|c|c|c|c|c|c|c|c|}
\hline 投与後時間 & 頭頂葉 & 視床下部 & 下垂体 & 副 腎 & 卯 鉴 & 子 宮 & 乳 腺 \\
\hline 30 分 & 0104 & 0231 & 4.656 & 1728 & 0.965 & 1.257 & 0.312 \\
\hline 分 & 0.040 & 0.073 & 2.626 & 1.016 & 0.590 & 0.498 & 0.201 \\
\hline 3 時 間 & 0.022 & 0024 & 0.952 & 0.438 & 0.155 & 0.198 & 0062 \\
\hline 24 時間 & 0.013 & 0009 & 0038 & 0019 & 0.031 & 0019 & 0.002 \\
\hline
\end{tabular}


また, 副腎, 卯巣など主要内分泌器官には特に多くの取 り込みはみられなかった。

\section{IV 考察}

Sulpiride の乳腺刺激作用が，イヌまたはラ，トて明 らかにみられることを以前われわれは報告した1７７９． この乱腺刺激作用唀発のメカニズムを検討するとき，被 検動物の内分泌器官の介在を無視することは出来ない.

Tranquillizing を呼ばれる作用を有する薬物が, ヒト 2) 10)や動物11) 12) て乳腺の増殖効果を示すことが多い が, その作用機序として, その薬物が哺乳動物の視床下 部化存在する Prolactin-Inh1 $b_{1}$ ting-Factor (P I F）の分泌を抑制し，その結果，下垂体からのブロラク チンの分泌を促進させるものであると考えられている4) 13)14)15). 他方, Barraclough16) Chlorpromazine がラ，ト卵巣ホルモンの分泌を促進 することを述べている. 正常ラ，トの卵巣ホルモンは乳 腺の増殖に必須のものであることはよく知られた事実て あり，また，卵巣ホルモンの1つであるエストロゲンが ブロラクチンの分泌を直接刺激すると考元られている 17)。更に, Selye ${ }^{18)}$ は, 副腎および卵巣を剔出したラ ハトに Estradiol とともに Cortisoneをあた党ると， 䟕腺の発育が著明にみられることを報告し, Johnsonら 19），副腎を有するラ，トで, ACTH やCortisol の 投与による乳腺発育効果を述べている. 最近, 乳腺組織 の体外培養で, その增殖分化にインシュリン, ブロラク チンのようなペプタイド, 卵巣ホルモン, 副腎皮質ホル モンのようなステロイドが必須てあることが明らかにさ れた。これらの報告にもとずき, Sulpirideの乳腺刺激 作用のメカニズム究明の試みとして, 内分泌腺剔出動物 を用いた実験を行なった。

下垂体剔出ラートに Sulp 1 rideの $100 \mathrm{mg} / \mathrm{kg}$ および 200 $\mathrm{mg} / \mathrm{kg}$ を皮下投与したが，いずれの投与群も乳腺の肥大 増殖勃果を示さなかった。 また, 同時に投与した Estradiol-17B 亿も乳腺刺激作用がみられなかった。. 要す るに，下垂体剔出動物ては性ホルモンの乳腺発育作用は みられないのて, この場合, 性ホルモンは主として下垂 体前葉を介して作用するものと考えられる。著者の実験 結果から, Sulpirideは, (1)視床下部一下垂体系を経て 始めて乳腺に効果を示すものて, (2)卵巣ホルモンが適量 あっても乳腺組織への直接作用は示さない，などと考元 られる.

卵巣を剔出したラノトでの Sulp 1 r $_{1}$ de の乳腺刺儌作 用は著者の観察ではほとんど認められなかった。一方， 卵剔動物への Estradiol 投与または Estradiol と
Sulp pride 併用投与はいずれも明らかな乳腺腺葉構造の 增殖をもたらし, 併用投与群にその効果はより強くあら われた. 卵剔ラ, トを用いた Sulpiride 投与群と Estradiol 投与群の乳腺增殖に関するこの差異は, (1) Sulpirıde に卵巣ホルモン様作用の無いこと, (2)卵巣ホ ルモンで条件づけられた乳腺組織のみが Sulpirideの 効果を表現しうることをうらずけるむのである. 卵巣ホ ルモン存在下の Sulpiride の明らかな乳腺刺激作用は プロラクチンの作用と極めて酷似している. Ben-David 20) む, 卵单剔出ラ, トを用い, Perphenazine 投与群 て同様の結果を報告している.

副腎剔出ラ，トに Sulpiride を投与した結果は, 正 常ラ,トへの作用と全く変らず, 被験ラ,トに明らかな 乳腺の肥大増殖を認めた。 この結果, Sulpiride の乳腺 刺激作用は，その効果の発現汇副腎を介さないものと考 えられる、ただ, ラ,トでは副副腎の存在が考えられて いるので, 今回の実験だけて, 直ちに副腎ホルモンの影 響を全く除外することはてきない. 正常ラットて, 副腎 皮質ホルモンをたはACTHが孚腺刺激作用をもつのは, これらのホルモンが下垂体または卵巣ホルモンの分泌に 促進的に働くのか子知れない.なお, 体外培盖実験で は, これらのホルモンが乳腺組織の分化と乳汁の産生分 泌に主に関連していることが明らかにされている。

Khazanら 21) は，ホルモン作用をもたない向精神薬を 用い, Ben-Davidら 22) は, Reserpine 類似物質を用い, 夫々の乳腺刺激勃果と中枢神経系鎮静勃果を比較検討し ているが, この領域の薬物に数多くの乳腺刺激物質のあ ることを報告している. Mishkinskyら23)は, Buthyrophenone 系化合物を用いたその研究て， tranquil一 lizine activity の 1 つ指標として用いた体温降下作 用が乳腺刺激効果とよく一致するものてあると述べてい る.しかし，著者の観察では, Sulp 1 ride の投与をうけ たウサギでの体温降下作用はほとえどみられず，対照薬 として使用した Chlorpromazine は強い体温降下作用 がみられた。このことは, 強い乳腺刺激作用を発揮する Sulpiride に. 種々の Phenothiazine 化合物類似の強 い major tranquillizing の作用がない, すなわち, tranquillizing の作用と乳腺刺激効果との解離を示唆 するものと思われる。

tranqu1llizing の作用を有する薬物が，ヒト24) や 動物25) 26)の血中ブロラクチン濃度に影響を及ぼすこと はよく知られている. 多くの向精神薬とは多少異なった 薬理効果を持つ Sulpiride が, 乳腺刺激作用を持つこ とを明らかにしてきたが, 当然血中プロラクチン濃度の 上昇が想像できる。これまての報告27)によれば，プロ 
ラクチン分泌促進因子が作用した際, 血中プロラクチン の変動は非常にすみやかにみられ，その上昇ないし低下 は数時間内に括こるものと考光られている．血中プロラ クチン值が Sulpiride 投与 6 時間後に正常值の 2.5 倍, 12時間後に 3 倍までに上昇し，24時間後には低下傾向を 示した.このことは Perphenazıneを用いた Blackwel1ら27)の報告とよく一致するものてある.

経時的に測定した血中プロラクチン值に対応した下垂 体組織内プロラクチン擃度の測定は試みられたが，それ は，12時間後に軽度減少，24時間後にはわずかな上昇を みた。このデータは，下垂体組織てのプロラクチンの放 出, 合成過程を示すものであろう。石田 ${ }^{28)}$ はラ ,卜下 垂体MT細胞の電顕観察て同様のこと, すなわち Sul一 pirrde 単一投与 6 時間以後における分泌顆粒放出像, 12時間以後における分泌顆粒産生像を報告している。 た, 最近小川ら 29) はヒトで, Debeljukら30) はラ,ト て, Sulpirideの血中プロラクチン変動がもっと短時間 に大きく変動することを報告している．

Ben-David4) は, Perphenazıneの乳腺刺激作用のメ カニズムとして, 視床下部よりのPIFの分泌抑制による 下垂体からのプロラクチン分泌の促進を考光ている．視 床下部内 PIF量の測定またはとの分泌抑制をチェノクす ることは本研究ててきなかったが, 放射性 Sulpiride の全身投与直後の中枢神経系における分布を検索してみ た. 大脸皮質, 視床下部, 下垂体の 3 部位につき, Sulpirideの取り込み量をたは蓄積量の経時的変動をみ たが，常に下垂体組織の濃度が高く，皮質部，視床下部 は非常にわずかなものであった。これらの観察は， Sulpirideが，下垂体酒直接作用し，下垂体からのプロラ クチン分泌を促進する作用を有することも考光られる. ただ，下垂体実質組織と下垂体内に含まれる血液とをわ けて Sulpiride 濃度を測定していない. Sulpiride 投 与後 1 日以内の下垂体は充血が強いことを著者らは観察 しているのて, Sulp 1 r 1 de の血中含有量が下垂体組織濃 度に影響を及ぼしている可能性は残っている。また，採 取された視床下部の濃度は一般に低かったが，PIFを分 泌する神経核領域のみの濃度は高いかも知れない。今 後, Autorad1ographyを利用した検索をすべきたろう。 Sjostrandら ${ }^{31)}$ は, Chlorpromazine の autoradiographyによるマウス体内分布実験で，大脳に打ける主な 分布部位が海馬および視床核にあることを示している。 Shan 1 $^{32)}$ は, Perphenazine の脳内取り込みが視床 下部に多いととを報告している。近年，Givantら ${ }^{33)}$ は，乳腺刺激作用を有するButhyrophenone系薬郕のラ ，トの体内分布を測定し，脳における最も高い濃度は視
床下部にみられたことを報告している。他方，Debeljuk

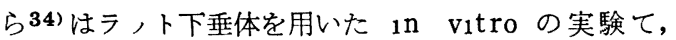
Sulp $1 r_{1}$ de が下垂体に直接作用してプロラクチンの分泌 を促進すること，さらにPIFの下垂体への作用をも抑制 することを述べている。

\section{$\mathrm{V}$ 結 論}

1) Sulpiride の乳腺刺激作用は，下垂体剔出動物や 卵巣剔出動物では認められず，副腎剔出動物では正常動 物とほぼ同様の程度にみられた。エストロケン投与の下 垂体剔出動物印卵巣剔出動物では, Sulpir 1 de $の$ 乳腺刺 激作用は前者てほとえどみられず，後者ては明らかであ った．以上より，Sulpiride の乳腺刺儌作用を内分泌器

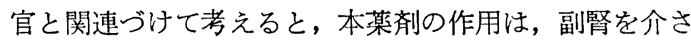
すに発現し，卵巣ホルモン類似のものてはなく，下垂体 を直接にまたは視床下部下垂体系を作用点として発揮さ れるものてある.

2) ウサギで Chlorpromazine は明らかな体温降下 作用を示したが，Sulpiride 亿はほとんどその作用がな く，一般の向精神薬とは多少その薬理効果を異にするこ とを明らかにし，Sulpir1deては乳腺刺激効果と神経系 への作用とが解離することを示唆した。

3 ）血清プロラクチン濃度は, Sulp $1 \mathrm{r}_{1}$ de 投与 6 時間 後て明らかな上昇を示し，12時間後をピークに以後徐ヶ に減少傾向を示した。また，下垂体組織内プロラクチン 含量は, Sulp $1 r_{1}$ de 投与12時間後に軽度減少し，24時間 後にわずかに上昇した. Sulp 1 r 1 de を数回または 1 か月 連続投与後の血清中プロラクチン值は, 乳腺組織が肥大 増生しているにもかかわらず，投与前の值と同程度であ った.

4) 放射性 Sulpiride のラ，卜体内分布が投与後経 時的に観察された。 大脑皮質，視床下部，下垂体ての単 位重量当りの濃度は, 下垂体に明らかな高値を認め, 視 床下部には低值しかみなかった。視床下部に比して下垂 体濃度が高いことは，Sulp $1 \mathrm{r}_{1}$ de が下垂体偪直接作用す る可能性を考えさせる，また，大脳皮質，卵巣，副腎， 乳腺への Sulp 1 r 1 de の取り込みも少ないのて, 乳腺へ の直接作用，あるいは大脳，卵巣または副腎を介する乳 腺刺激作用は考元られない。

\section{謝 辞}

稿を終るに臨み，終始御懇管な御指導並びに御校閲を 睗わりました森井外吉教授に深甚なる谢意をささげます と共に, 本研究を遂行するに当り, 御助力, 御協力をい ただきました藤沢薬品中央研究所なっしに関西医大病理 学教室の皆様に心から感射いたします。 
1）藤井登志之：Sulpirideの乳腺刺激作用に関する 研究, I. Sulpiride の乳腺刺激作用に関する形 態学的観察, 関西医大誌

2) Sulman, F. G. and Winnik, H. Z. : Hormonal effects of Chlorpromazine. Lancet. 1, 161 〜62, 1956.

3) Polichuk, W.Z. and Kulcsar, S. : Effects of Chlorpromazine on pituitary function. J. Clin. Endocrinol. 16, 292 293, 1956.

4) Ben-David, M. : Mechanism of induction of mammary differentiation in SpragueDawley female rats by Perphenazine. Endocrinol. 83, 1217 1223, 1968.

5）田中 明: ラット脳下垂体摘出法, 塩野義研究所 年報, 5, 678 680, 1955.

6) Niswender, G. D. , Chen, C. L., Midgley, A.R., Meites, J. and Ellis, S. : Radioimmunoassay for rat prolactin. Proc. Soc. Exp. Biol. Med. 130, 793 797, 1969.

7）森井外吉, 藤井登志之, 中井 徹 : Sulpiride の ラットの乳腺および性器に及ぼす効果, 応用薬理 7, 1379 1383, 1973.

8）森井外吉, 藤井登志之 : Sulpiride の体内分布実 験, 未発表,

9）森井外吉, 東条伸平, 望月真人，大沢悦二，足高 善彦, 藤井登志之, 中井 徹: Sulpirideのイヌ の乳腺および性器に及ぼす効果，応用薬理，7, 1371 1378, 1973.

10) Lampe, W. T. : Lactation following psychotropic agents. Metabolism. 16, 257 258, 1967.

11) Sulman, F. G. and Minnik, H. Z. : Hormonal depression due to treatment of animals with Chlorpromazine. Nature 178, 365. 1956.

12) Meites, J. : Induction of lactation in rabbits with Reserpine. Proc. Soc. Exp. Biol. Med. 96, 728 730, 1957.

13) Schally, A. V., Kuroshima, A ., Ishids, Y. Redding, T.W. and Bowers, C. Y. : The presence of prolactin inhibiting factor (P.I.F.) in extracts of beef, sheep, and pig hypothalamus. Proc. Soc. Exp. Biol.
Med. 118, 350 352 1965.

14) Grosvenr, C. E. , McCann, S. M. and Nallar, R. : Inhibition of nursing-induced and stress-induced fall in pituitary prolactin concentration in lactating rats by injection of acid extracts of bovine hypothalamus. Endocrinol. 76, 883 889, 1965.

15) Ratner, A., Talwalker, P.K. and Meites, J. : Effect of Reserpine on prolactininhibiting activity of rat hypothalamus. Endocrinol. 77, 315 319, 1965.

16) Barraclough, C. A. : Induction of pseudopregnancy in the rat by Reserpine and Chlorpromazine. Endocrinol. 65, 563, 1959.

17) Ramirez, V.D. and McCann, S. M. : Induction of prolactin secretion by implants of estrogen into the hypothalamo-hypophysial region of female rats. Endocrinol. 75, 206, 1964.

18) Selye, $\mathbf{H}$. : The effect of cortisol upon the mammary glands. Acta. Endocrinol. 17, 394 401, 1954.

19) Johnson, R, M. and Meites, J. : Effects of cortisone, hydrocortisone and ACTH on mammary growth and pituitary prolactin content of rats. Proc. Soc. Exp. Biol. Med. 89, 455 458, 1955.

20) Ben-David, M. : Role of the ovaries in perphenazine induced lactation. J. Endocrinol. 41, 377 385, 1968.

21) Khazan, N., Ben-David, M., Mishkinsky. J., Khazen, K. and Sulman, F. G. : Dissociation between mammotropic and sedative effects of non-hormonal hypothalamic tranquillizers. Arch. int. Pharmacodyn. 164, 258 271, 1966.

22) Ben-David, M. , Khazen, K. Khazan, N. and Sulman, F.G. : Correlation between depressant and mammotropic effects of fifteen Reserpine analogues Arch. Int. Pharmacodyn. 171, 274 284, 1968.

23) Mishkinsky, J., Khazen, K., Givant, Y., Dikstein, S. and Sulman, F. G. : Mammot- 
ropic and neuroleptic effects of Butyrophenones in the rat. Arch. Int. Pharmacodyn. 179, 94 105, 1969.

24) Friesen, H., Guyda, H., Hwang, P., Tyson, J.E. and Barbeau, A. : Functional evaluation of prolactin secretion. ; A guide to therapy. J. Clin. Invest. 51, 701 709, 1972.

25) Bryant, G.D. and Greenwood, F.C.':Plasma prolactin levels in the goot. ; Physiological and experimental modification.

J. Endocrinol. 40, iv v, 1968.

26) Bryant, G. D., Connan, R. M. and Greenwood, F.C. : Changes in plasma prolactin induced by acepromazine in sheep. J. Endocrinol. 41, 613 614, 1968.

27) Blackwell, R., Vale, W., River, C. and Guillemin, R. : Effect of Perphenazine on the secretion of prolactin in vivo and in vitro. Proc. Soc. Exp. Biol. Med. 142, 68 71, 1973.

28）石田 明：Sulpiride 投与ラット下垂体MT細胞 亿関する電顕細胞学的研究, 関西医大誌, 28, 137 $\sim 167,1976$.

29）小川紀雄, 山内治郎, 高原二郎, 大藤 真: Sulpiride によるプロラクチン分泌，ホルモンと臨
床, 23, 927 929, 1975.

30) DebelJuk, L., Rozados, R., Daskal, H., Velez, C. V. and Mancini, A. M. : Acute and chronic effects of Sulpiride on serum prolactin and gonadotropin levels in castrated male rats. Proc. Soc. Exp. Biol. Med. 148, 550 552, 1975.

31) Sjöstrand, S.E : Cassans, G. B. and Hansson, E. : The distribution of ${ }^{35} \mathrm{~S}-\mathrm{Ch} l o r-$ promazine in mice studied by whole body autoradiography. Arch. int. Pharmacodyn. 156, 34 47, 1965.

32) Shani, J., Givant, Y., Sulman, F. G., Eylath, U. and Eckstein, B. : Commpetition of Phenothiazines with oestradiol for oestradiol receptors in rat brain. Neuroendocrinol. 8, 307 316, 1971.

33) Givant, Y., Shani, J., Goldhaber, G., Serebrenik, R. and Sulman, F. G. : Pharmacology of three mammotropic Buthyrophenones in the rat. Arch. int Pharmacodyn. 205, 317 327 1973.

34) Debeljuk, L., Daskal, H., Rozados, R. and Guitelman, A. : Effect of Sulpiride on prolactin release by rat pituitaries in vitro. Experientia 30, 1355 1356, 1974.

\section{VII 写真説明}

写真 1 ：無処置対照ラット乳腺 $\mathrm{H}-\mathrm{E}$ 染色 $\times 100$ $\mathrm{D}:$ 乳管

写真 $2 ：$ 下垂体剔出後 17 日目ラット乳腺 $\mathrm{H}-\mathrm{E}$ 染色 $\times 100$ $\mathrm{D}:$ 乳管

写真 3 ：下垂体剔出後 Sulpiride $100 \mathrm{mg} / \mathrm{kg}$ を 2 週間皮下投与したラット乳腺 $\mathrm{H}$-E染色 $\times 100$ $\mathrm{D}:$ 乳管

写真 4 ：下垂体剔出後 Estradiol-17 $\beta$ を 2 週間皮下投与したラット乳腺 $\mathrm{H}$-E染色 $\times 100$ $\mathrm{D}:$ 乳管

写真 5 ：卵巣剔出後 Sulpiride $100 \mathrm{mg} / \mathrm{kg}$ を 2 週間皮下投与したラット乳腺 $\mathrm{H}$ - $\mathrm{E}$ 染色 $\times 100$ $\mathrm{A}:$ 腺葉

写真 6 ：卵巣剔出後 Estradiol-17 $\beta$ を 2 週間皮下投与したラット乳腺 $\mathrm{H}$-E染色 $\times 100$ $\mathrm{A}:$ 腺葉

写真 7 ：卵巣剔出後 Sulpiride $100 \mathrm{mg} / \mathrm{kg}$ 私よび Estradiol-17 $\beta$ を 2 週間併用投与したラット乳腺 $\mathrm{H}-\mathrm{E}$ 染色 $\times 100$ $\mathrm{A}:$ 腺葉

写真 8 ：副腎剔出後 Sulpi ride $100 \mathrm{mg} / \mathrm{kg}$ を 2 週間皮下投与したラット乳腺 $\mathrm{H}$-E染色 $\times 100$ $\mathrm{A}:$ 腺葉 


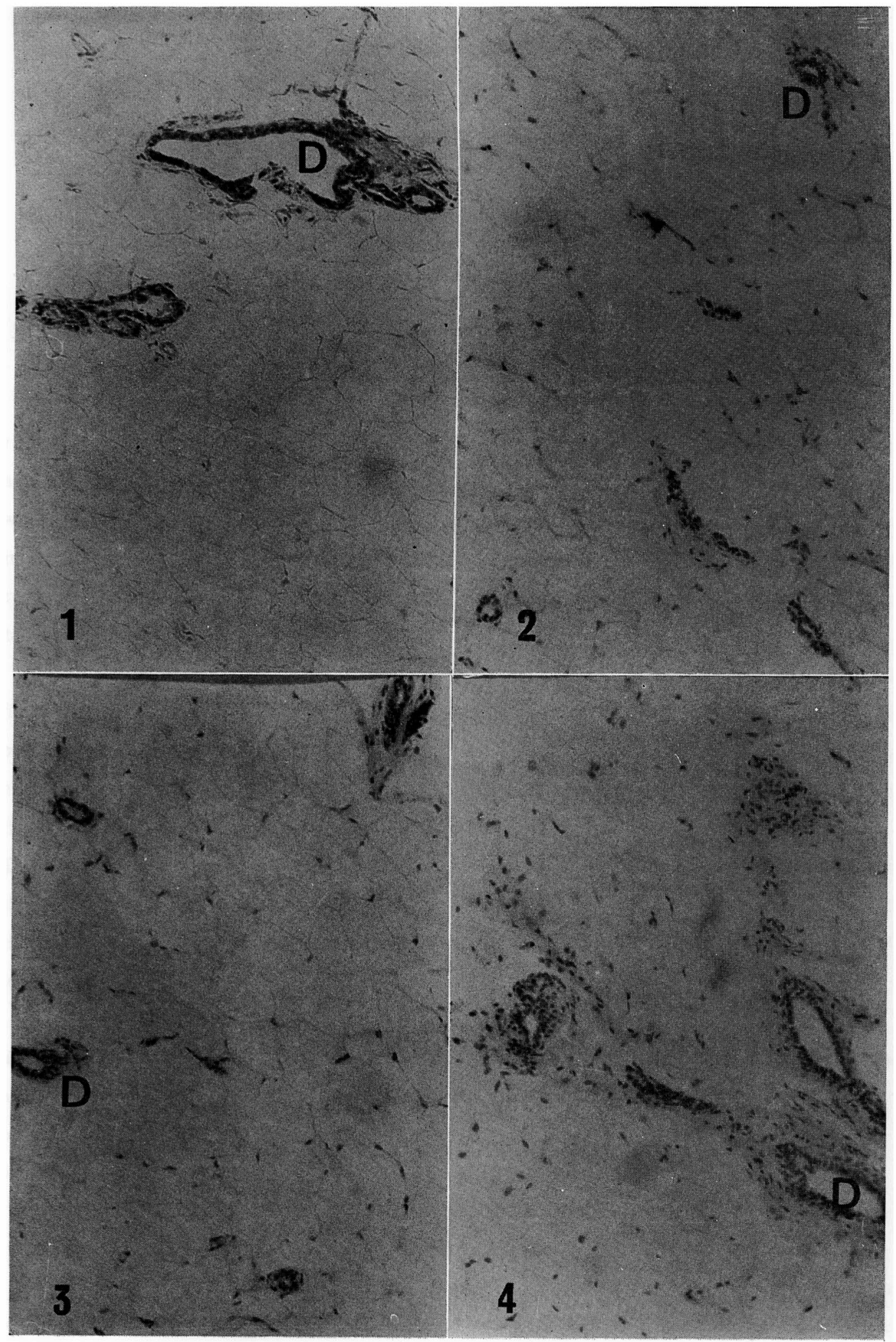




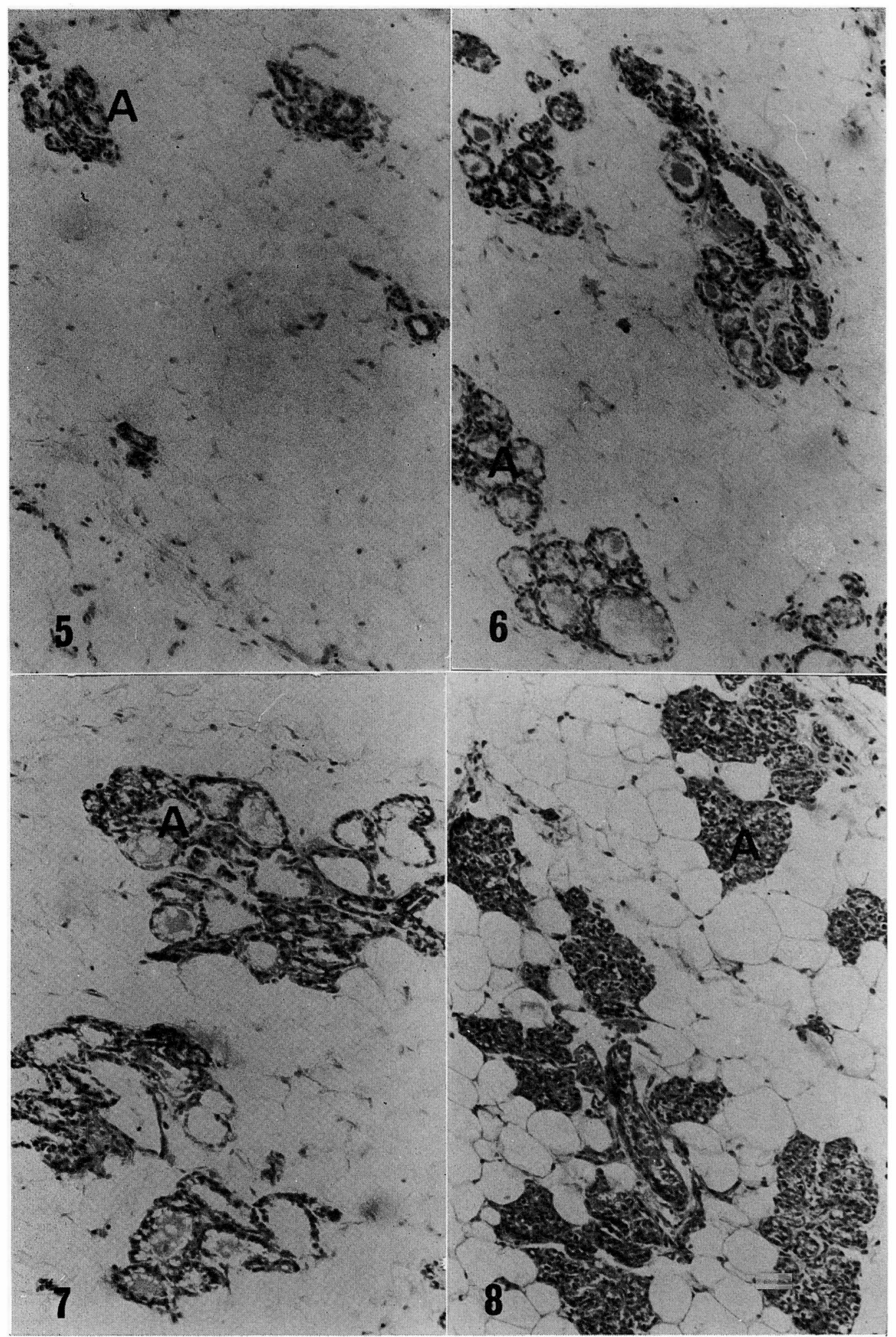




\title{
(欧 文抄 録)
}

\section{Studies on Mammotrophic Action of Sulpiride \\ Part II Mechanism of Mammotrophic Action with Sulpiride in Female Rats}

\author{
Toshiyuki Fujii \\ Department of Pathology, Kansai Medical University, \\ Moriguchi, Osaka, Japan \\ (Supervised by Prof. S. Morii)
}

No mammotrophic action of Sulpiride could be detected on both the hypophysectomized rats injected subcutaneously by either $100 \mathrm{mg} / \mathrm{kg}$ or $200 \mathrm{mg} / \mathrm{kg}$ of the drug daily for 2 weeks and the ovariectomized rats injected subcutaneously with $100 \mathrm{mg} / \mathrm{kg}$ of the drug daily for 2 weeks. Daily injection of Estradiol-17 $\beta, 10 \gamma$, into the hypophysectomized ones could not induce to reveal the action of Sulpiride, but it into the ovariectomized animals could reveal the mammotrophic action of the drug. Bilateral adrenalectomy could not disturbe to reveal the action of Sulpiride.

Radioimmunoassay for prolactin was performed on the serum and pituitary tissue of the diestrous females, which had been checked regular sex cycles in 2 weeks, 6, 12 and 24 hours after the subcutaneous injection of Sulpiride, $100 \mathrm{mg} / \mathrm{kg}$. A single dose of the drug elevated the serum prolactin levels to about 3 times that of the controls $6 \sim 12$ hours after the injection, when the pituitary contents were somewhat lower than that of the controls. The level in serum still elevated about 2.5 times 24 hours after the administration, when the content in the adenohypophysis increased 2 times that of the controls. On the sera of the rats injected daily, prolactin levels went down gradually and returned to normal level more than 7 days after the first injection.

Distribution of the radioactivity were determined on the mammary fatty pad, ovary, adrenal gland, hypophysis, hypothalamus and brain of the rats $1 / 2,1,3$ and 24 hours after the intramuscular injection of ${ }^{14} \mathrm{C}$-Sulpiride, $2 \mathrm{mg} / \mathrm{kg}$, respectively. Higher activity in the pituitary tisssues might suggest the direct action of the drug into the adenohypophysis.

In the rabbits, Chlorpromazine induced lower body temperature but Sulpiride, $100 \mathrm{mg} / \mathrm{kg}$, could not induce lower body temperature in 6 hours after the subcutaneous injection.

In summary, Sulpiride would act the adenohypophysis directly, and induce hypersecretion of prolactin in short time after the administration. Stimulation of prolactin could develope 
a proliferation with secretion on the mammary glands of the estrogenized animals. On the process of mammotrophic action with Sulpiride, the brain, adrenals and probably hypothalamus might have no direct actions. 